\title{
The Changing Business of Journalism and its Implications for Democracy
}

Edited by David A. L. Levy and Rasmus Kleis Nielsen

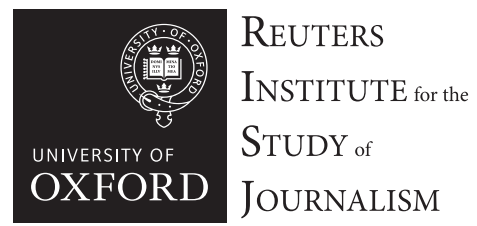





\section{Contents}

1. The Changing Business of Journalism and its Implications for Democracy

Rasmus Kleis Nielsen and David A. L. Levy

2. A Business Perspective on Challenges Facing Journalism

Robert G. Picard

3. Online News: Recent Developments, New Business

Models and Future Prospects

Sacha Wunsch-Vincent

4. The Strategic Crisis of German Newspapers

Frank Esser and Michael Brüggemann

5. The Unravelling Finnish Media Policy Consensus?

Hannu Nieminen

6. The French Press and its Enduring Institutional Crisis

Alice Antheaume

7. The Press We Destroy

John Lloyd

8. News in Crisis in the United States: Panic - And Beyond Michael Schudson

9. The Changing Landscape of Brazil's News Media Mauro P. Porto

10. The Business of 'Bollywoodized' Journalism

Daya Kishan Thussu

11. Which Way for the Business of Journalism?

Rasmus Kleis Nielsen and David A. L. Levy

List of contributors

Acknowledgements 



\section{Executive summary}

The business of journalism is widely held to be in serious crisis today, in particular because of the rise of the internet. This has potentially disastrous consequences for forms of democratic politics that have evolved hand-in-hand with private-sector mass media as we have known them in the twentieth century. This book includes chapters from around the world critically evaluating the notion of crisis, identifying both the common underlying cyclical, technological and long-term challenges that commercial news media organisations around the world face and the important, persistent national differences in audience demand, market structure and media regulation that suggest different likely future scenarios for different countries.

While the news industry has certainly suffered severe declines in revenues in several countries in recent years, the latest downturns seem to be more closely connected with the relative degree of dependence on volatile revenue sources like advertising and on the differential impact of the global recession than with the spread of the internet. This is illustrated perhaps most forcefully by the difference between countries like the United States and the United Kingdom, where the private media sector have struggled in recent years, whereas countries like Germany and Finland - with comparable levels of internet penetration and use and strong public service media organisations operating on several platforms - have seen much more stable developments in the business of journalism. Both the news industry and the journalistic profession are changing rapidly as new tools are being appropriated by journalists, sources and audiences, but the supposed crisis is far from universal, and the outcomes of current transformations far from certain.

The differences identified and documented in this book not only highlight the enduring relevance of inherited national differences in audience demand, market structure and media regulation, but also that, despite deterministic (and often fatalistic) claims to the contrary, there is still time for the business of journalism to reinvent itself and move into the twenty-first century, provided media managers, professional journalists, and policy-makers and the citizens they represent are willing to learn from different developments around the world.

The value of the chapters to follow lies in their detailed assessment of particular challenges or cases, and we will not attempt to summarise them here, but simply highlight a few particularly important points from each. In Chapter 1, Rasmus Kleis Nielsen and David A. L. Levy present a wide array of data to establish that different national media systems are developing very differently even as legacy media face 
comparable cyclical, technological and long-term challenges. In Chapter 2, Robert G. Picard reminds us that general interest news never was a profitable business in itself, but always cross-subsidised by other interests, whether commercial or political. In Chapter 3, Sacha Wunsch-Vincent reviews recent technological developments to show how new information and communications technologies have changed the value chain of news businesses, how journalists work, how audiences use news, and how they are increasingly transforming the wider communications environment as new players like aggregators and search engines rise to prominence. In Chapter 4, Frank Esser and Michael Brüggemann show how well the German media system has withstood current pressures, and argue that, in so far as there are any signs of crisis there, it is not a crisis for democracy or journalism in general, but at most a strategic crisis for newspapers in particular. In Chapter 5, Hannu Nieminen presents an overview of developments in Finland, where most commercial legacy media organisations also seem to have weathered the storm relatively well, despite high levels of internet penetration and use and the presence of a strong public service media organisation in YLE. However, Nieminen points out, the post-war media policy consensus within which this apparently sturdy media system developed may now be unravelling. In Chapter 6, Alice Antheaume underlines that crisis is nothing new in the French press, still constrained by systems of distribution and production developed to deal with post-Second World War shortages and never subsequently reformed, systems that today leave the newspaper industry in perennial crisis and reliant on periodic bailouts by the state. In Chapter 7, John Lloyd reviews the situation in the United Kingdom, discusses the extent to which new forms of peer-to-peer production can make up for what is lost when inherited forms of journalistic work are displaced or destroyed, and underlines the enduring relevance of traditional news journalism. In Chapter 8, Michael Schudson reflects upon the case of the United States, where the current crisis has hit first - and hardest - and sketches out likely scenarios for the immediate future and their democratic implications. Chapters 9 and 10 turn the focus to the business of journalism in two emerging economies where the picture looks rather different. In Chapter 9, Mauro P. Porto underlines not only how the Brazilian media are still struggling with debt acquired during the 1990s, but also how many parts of the sector, in particular TV but also the press, are now profiting from sustained economic growth, increasing literacy, and declining poverty. In Chapter 10, Daya Kishan Thussu shows how dramatically the Indian media have grown since the sector was liberalised in the 1990s, but also how most of the content produced is largely 'Bollywoodized', focusing on entertainment and sensational soft news rather than hard news covering public affairs. In Chapter 11, Rasmus Kleis Nielsen and David A. L. Levy write about current policy discussions; they underline the need to take into account the widely different situations the media industry in general and the business of journalism in particular face in different countries - even when confronted with comparable challenges - but also the need for national policy-makers to look beyond their traditional national policy toolkits. 